\title{
Single-Pot ZnO Nanostructure Synthesis by Chemical Bath Deposition and their applications
}

Venkata Manthina ${ }^{\mathrm{a}, \mathrm{b}}$, Alexander G. Agrios ${ }^{\mathrm{a}, \mathrm{b}}$

a, Department of Civil \& Environmental Engineering, University of Connecticut, 261 Glenbrook Rd Unit 2037, Storrs, CT 06269, USA

b, Center for Clean Energy Engineering, University of Connecticut, 44 Weaver Rd, Storrs, CT 06269-5233, USA

Corresponding author: venkata.manthina@uconn.edu

\begin{abstract}
$\mathrm{ZnO}$ is commonly synthesized using a many different techniques. Among them, the chemical bath deposition (CBD) technique is appealing as it is low cost and environmentally friendly, owing partly to the low temperature conditions used. An exploration of the variety of $\mathrm{ZnO}$ nanostructures that can be synthesized using this technique is presented in this study. ZnO fibers, nanorods, cauliflowers, nanorod balls, nanoforest, nanopencils, ellipsoids and nanotubes are synthesized using CBD by using different additives and conditions that alter the growth of the $\mathrm{ZnO}$ nanostructures. The application of these nanostructures in wide variety of devices is analyzed.
\end{abstract}

\section{Keywords}

$\mathrm{ZnO}$, nanorods, nanowires, nanoflowers, nanosheets, chemical bath deposition, nanostructures

\section{Introduction}

Rational design and control over morphology and functional properties of inorganic nanostructures is long standing goal in nanoscience and engineering [1]. The physical and chemical properties of a material can be changed by designing architectures which can create interfacial effects. Materials with desired properties can be designed using morphology control, leading to potential applications. Therefore there is a need for morphology and property control 
of materials. Over the last twenty years significant effort to scale the semiconductor and metal oxide nanostructures with the effects at nanoscale has been explored vigorously to improve efficiency of wide variety of devices like solar cells, batteries and fuel cells [2, 3].

$\mathrm{ZnO}$ is one of the most favorable materials widely used in electronics (transistors) [4, 5], sensors [6-8], catalysts [9-11], light emitting devices [12-15], piezoelectric devices [16-20], solar cells [21-23], sunscreens [24, 25], lasers diodes [26, 27], hydrophobic surfaces [28, 29], magnetic data storage [30, 31], water disinfection [32], antiviral agent [33, 34], anti-cancer agent [35], hazardous waste remediation [36], flexible plastic devices [37], degradation of pollutants [38], energy conversion and storage devices [22, 39-41]. $\mathrm{ZnO}$ is a wide band gap semiconductor (3.3 $\mathrm{eV})$ with a high excitation binding energy of $60 \mathrm{meV}[42]$ at room temperature.

The properties of the $\mathrm{ZnO}$ nanostructures can be altered by tailoring the size, shape, facets, surface area and concentration of the oxygen vacancies. Many useful properties of $\mathrm{ZnO}$ nanorods are dependent on the rod diameter, length and number density. The surface band bending of the $\mathrm{ZnO}$ nanorods is dependent on the diameter of the $\mathrm{ZnO}$ nanorods $[43,44]$. The performance of the photoelectrochemical cells for water splitting and photovoltaics depends on the rod morphology $[45,46]$. In hybrid solar cells, a low density of $\mathrm{ZnO}$ nanorods on the photoanode is needed to provide void space for P3HT:PCBM infiltration [47]. For applications in surface acoustic wave devices growth along the $a$-axis is required [48]. In the fabrication of composite nanostructures such as nanoparticle-coated $\mathrm{ZnO}$ nanorods, tuning the density of the nanorods is required for balancing total surface area against effective coverage of the nanoparticles throughout the length of the nanorod $[22,49]$. The optoelectronic and gas sensing properties of the $\mathrm{ZnO}$ is dependent on the shape of nanostructures [50]. The photocatalytic activity of the $\mathrm{ZnO}$ nanorods is enhanced by increasing surface defects and aspect ratio [51, 52]. In Organic light 
emitting diodes threefold increase in the efficiency was observed by using triangular shaped $\mathrm{ZnO}$ nanoparticles [53]. Blue and white light emission was on $\mathrm{ZnO}$ nanoforest under high voltage [54].

$\mathrm{ZnO}$ nanorods can be grown in situ from a variety of substrates through procedures such as chemical bath deposition [55, 56], electrodeposition [57-59], chemical vapor deposition [60, 61], thermal deposition [62], laser ablation in liquid [63, 64], vapor-liquid-solid growth [65], thermal annealing using catalyst [66], flame transport synthesis [33], plasma synthesis [67], combustion synthesis [68], microwave synthesis [69] and pulse laser deposition [70]. Among these, chemical bath deposition (CBD) has the advantage of being low temperature, low cost, suitable for large area processing for industrial applications, and environmentally benign. CBD is a two-step process, beginning with the deposition of a "seed layer" of $\mathrm{ZnO}$ nanocrystals on the substrate, from which nanorods are subsequently grown in the "chemical bath", an aqueous solution of a zinc precursor with additives to modify the growth.

In this study we have grown variety of $\mathrm{ZnO}$ nanostructures and their suitability to different applications based on the size, shape, surface area is discussed. This article provides an overview of the synthesis of the different $\mathrm{ZnO}$ structures and their suitable application.

\section{Experimental}

\subsection{Reagents and materials}

Zinc nitrate hexahydrate, hexamethylenetetramine (HMTA), polyethyleneimine, citric acid, cobalt nitrate hexahydrate, ammonium hydroxide and ethanol were purchased from SigmaAldrich (USA) and were ACS grade. $\mathrm{SnO}_{2}: \mathrm{F}$ glass (FTO, transmission $>80 \%$ in the visible spectrum; sheet resistance $8 \Omega$ / square) was purchased from Hartford Tec Glass (USA). 


\subsection{ZnO seed crystal synthesis}

The $\mathrm{ZnO}$ seeds were synthesized by dissolving of $5 \mathrm{mM}$ zinc acetate dihydrate in ethanol. The formation of $\mathrm{ZnO}$ seeds began with the dissolution of $5 \mathrm{mM}$ zinc acetate dihydrate in ethanol by stirring for 3 hours at room temperature [71]. Deionized water is added to the seed solution for increasing the size of the $\mathrm{ZnO}$ seeds [72].

\subsection{Pre-cleaning of FTO substrates}

The FTO substrates were cleaned in RBS 35 detergent with 2\% ((v/v) solution using sonication for 5 minutes. RBS sonicated FTO substrates were rinsed in deionized water and sonicated in ethanol and acetone for 5 minutes respectively. After sonication the samples are dried in the flow of nitrogen.

\subsection{Seed layer deposition}

The seed crystals synthesized as described in section 2.2 were deposited on the precleaned FTO substrate using drop coating technique. Drops of seed crystal solution (10 $\mu 1)$ were deposited onto the pre cleaned FTO substrates using a calibrated micropipette. The drops were allowed to dry for $1 \mathrm{~min}$ under room temperature in laboratory conditions. After drying of the seed layer the FTO substrate was rinsed in ethanol and dried in the flow of nitrogen gas. Two seed layers were deposited on all the substrates. After the deposition FTO glass is sintered at $350^{\circ} \mathrm{C}$ for 30 minutes on Ti hot plate and allowed to cool down to room temperature.

\subsection{ZnO nanofiber synthesis}


Nanofibers were grown by using chemical bath deposition. The precleaned FTO substrates were placed in an aqueous solution of $50 \mathrm{mM}$ zinc nitrate hexahydrate, and $12 \mathrm{mM}$ citric acid in a $100-$ $\mathrm{ml}$ glass bottle at $90^{\circ} \mathrm{C}$ for 24 hours.

\subsection{ZnO nanotubes synthesis}

Nanotubes were grown by using chemical bath deposition. The seeded substrate was covered with scotch tape to decrease the area of deposition by 50\%. The seeded FTO substrates were placed in an aqueous solution of $50 \mathrm{mM}$ zinc nitrate hexahydrate, and $6 \mathrm{mM}$ polyethyleneamine in a 100-ml glass bottle at $90^{\circ} \mathrm{C}$ for 24 hours. The glass bottle was left for one hour for cooling before the sample was removed and cleaned in ethanol and dried in the stream of nitrogen.

\subsection{ZnO nanoflowers synthesis}

Nanoflowers were grown by using chemical bath deposition. Precleaned FTO substartes are coated with 1 day aged seed layer solution. The FTO substrates were placed in an aqueous solution of $50 \mathrm{mM}$ zinc nitrate hexahydrate, and $0.35 \mathrm{M}$ ammonium hydroxide in a $100-\mathrm{ml}$ glass bottle at $90^{\circ} \mathrm{C}$ for 24 hours.

\subsection{ZnO nanorods Synthesis}

Nanorods were grown from the $\mathrm{ZnO}$ seeds by chemical bath deposition. The seeded FTO substrates were placed in an aqueous solution of $45 \mathrm{mM}$ zinc nitrate hexahydrate, $50 \mathrm{mM}$ hexamethylenetetramine and $6 \mathrm{mM}$ polyethyleneimine in a $100-\mathrm{ml}$ glass bottle at $90^{\circ} \mathrm{C}$ for 24 hours. 


\subsection{ZnO nanoforest Synthesis}

Nanoforest were grown by using chemical bath deposition. The 0M water seeded FTO substrates were placed in an aqueous solution of $25 \mathrm{mM}$ zinc nitrate hexahydrate and hexamethylenetetramine, and $12 \mathrm{mM}$ polyethyleneamine in a $100-\mathrm{ml}$ glass bottle at $80^{\circ} \mathrm{C}$ for 24 hours.

\subsection{ZnO nanoball synthesis}

Nanorods were grown from the $\mathrm{ZnO}$ seeds by chemical bath deposition. The seed layer solution is prepared with $1 \mathrm{M} \mathrm{H}_{2} \mathrm{O}$ in the seed solution for forced hydrolysis [72] and aged for 24 hours before seed layer deposition. The seed layer deposited FTO glass is sintered at $350^{\circ} \mathrm{C}$ for 30 minutes on $\mathrm{Ti}$ hot plate and allowed to cool down to room temperature. The seeded FTO substrates were placed in an aqueous solution of $45 \mathrm{mM}$ zinc nitrate hexahydrate, $5 \mathrm{mM}$ cobalt nitrate hexahydrate, $50 \mathrm{mM}$ hexamethylenetetramine and $6 \mathrm{mM}$ polyethyleneimine in a $100-\mathrm{ml}$ glass bottle at $90^{\circ} \mathrm{C}$ for 24 hours.

\subsection{ZnO cauliflower synthesis}

$\mathrm{ZnO}$ Cauliflower morphology was grown by chemical bath deposition. The seed layer solution is prepared as described previously [72] briefly described in section 2.2. The seed layer deposited FTO glass is sintered at $350^{\circ} \mathrm{C}$ for 30 minutes on Ti hot plate and allowed to cool down to room temperature. The seeded FTO substrates were placed in an aqueous solution of $25 \mathrm{mM}$ zinc nitrate hexahydrate, $25 \mathrm{mM}$ hexamethylenetetramine, $250 \mathrm{mM}$ ammonium hydroxide and $6 \mathrm{mM}$ polyethyleneimine in a $100-\mathrm{ml}$ glass bottle at $100^{\circ} \mathrm{C}$ for 24 hours.

\subsection{ZnO pencil shaped nanorod synthesis}


$\mathrm{ZnO}$ pencil morphology was grown by chemical bath deposition. The seed layer solution is prepared as described previously [72] briefly described in section 2.2. The seed layer deposited FTO glass is sintered at $350^{\circ} \mathrm{C}$ for 30 minutes on Ti hot plate and allowed to cool down to room temperature. The seeded FTO substrates were placed in an aqueous solution of $50 \mathrm{mM}$ zinc nitrate hexahydrate, $50 \mathrm{mM}$ hexamethylenetetramine and $6 \mathrm{mM}$ polyethyleneimine in a $100-\mathrm{ml}$ glass bottle at $90^{\circ} \mathrm{C}$ for 16 hours. Fresh precursor solution is introduced for every four hours. After the growth the sample is cleaned in ethanol and dried in flow of nitrogen and sintered at $500^{\circ} \mathrm{C}$ for 1 hour.

\subsection{ZnO nanoweb structures}

Nanoweb structures were grown by using chemical bath deposition. Precleaned FTO substrates are coated with seed layer solution of $5 \mathrm{mM}$ zinc acetate dehydrate in ethanol. The seed layer deposited FTO glass is sintered at $350^{\circ} \mathrm{C}$ for 30 minutes on Ti hot plate and allowed to cool down to room temperature. The seeded FTO substrates were placed in an aqueous solution of $50 \mathrm{mM}$ equimolar zinc nitrate hexahydrate and hexamethylenetetramine and $0.7 \mathrm{M}$ ammonium hydroxide in a $100-\mathrm{ml}$ glass bottle at $90^{\circ} \mathrm{C}$ for 24 hours.

\subsection{ZnO ellipsoidal particles}

Ellisoidal structures were grown from chemical bath deposition. Precleaned ITO substrates are coated with seed layer solution of $5 \mathrm{mM}$ zinc acetate dehydrate in ethanol. The seed layer deposited ITO glass is sintered at $350^{\circ} \mathrm{C}$ for 30 minutes on Ti hot plate and allowed to cool down to room temperature. The seeded ITO substrates were placed in an aqueous solution of $150 \mathrm{mM}$ equimolar zinc nitrate hexahydrate and hexamethylenetetramine in a $100-\mathrm{ml}$ glass bottle at $90^{\circ} \mathrm{C}$ for 24 hours. 


\subsection{ZnO platelets}

Nano platlets structures were grown from chemical bath deposition. Precleaned FTO substrates are coated with seed layer solution of $5 \mathrm{mM}$ zinc acetate dehydrate in ethanol modified using forced hydrolysis at $80^{\circ} \mathrm{C}$ with $0.8 \mathrm{M}$ DI water. The seed layer deposited FTO glass is sintered at $350^{\circ} \mathrm{C}$ for 30 minutes on $\mathrm{Ti}$ hot plate and allowed to cool down to room temperature. The seeded FTO substrates were placed in an aqueous solution of $150 \mathrm{mM}$ equimolar zinc nitrate hexahydrate and hexamethylenetetramine in a $100-\mathrm{ml}$ glass bottle at $90^{\circ} \mathrm{C}$ for 24 hours.

\subsection{Characterization}

The morphology of $\mathrm{ZnO}$ nanostructures was investigated by scanning electron microscopy (FEI Quanta FEG250 SEM in high vacuum mode) equipped with energy-dispersive X-ray spectroscopy (EDX). The $\mathrm{ZnO}$ nanorods and $\mathrm{TiO}_{2}$ nanoparticles were additionally characterized by X-ray powder diffraction (XRD) using a Bruker D8 Advance X-ray diffractometer using Cu $\mathrm{K} \alpha$ radiation $(\lambda=0.154178 \mathrm{~nm})$ at a scanning rate of $0.04^{\circ} \mathrm{s}^{-1}$ in the $2 \theta$ range from $10^{\circ}$ to $90^{\circ}$. The XRD data were analyzed using the Debye-Scherrer equation to determine the crystallite size.

\section{Results and Discussion}

$\mathrm{ZnO}$ nanostructure synthesis involves four steps seed layer solution, seed layer deposition, sintering of the seeded substrates and growth of the nanostructures. 

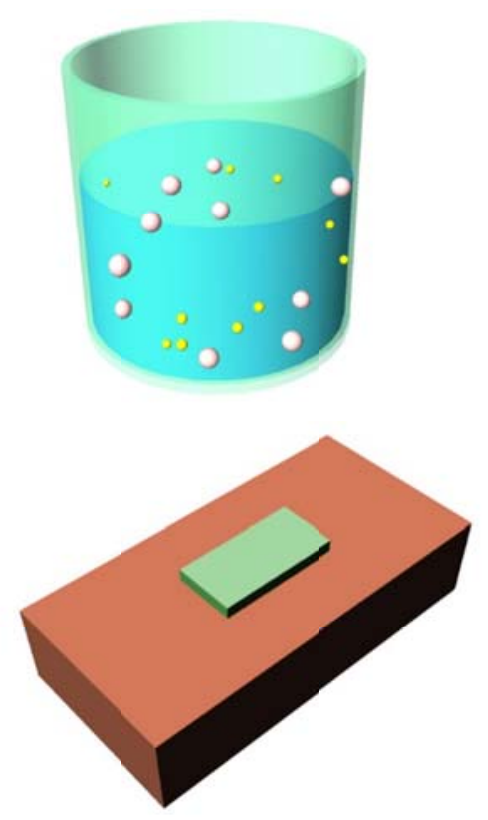
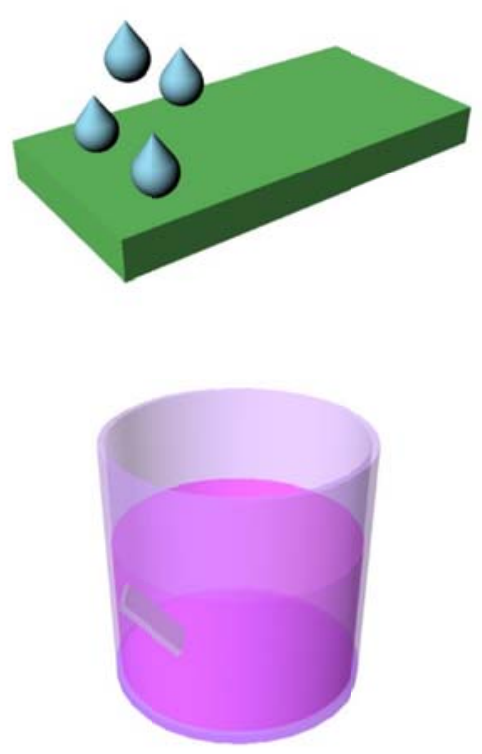

Figure 1. Schematic of the $\mathrm{ZnO}$ nanostructure growth process.

\subsection{ZnO seed crystals}

The $\mathrm{ZnO}$ nanostructures grow with the seeds typically $2-3 \mathrm{~nm}$ in diameter. We increased the size of the $\mathrm{ZnO}$ seeds by using forced hydrolysis by adding controlled amounts of water to the seed crystal solution during the synthesis. $\mathrm{ZnO}$ seeds have important effects on the growth and morphology of the $\mathrm{ZnO}$ nanostructures [72]. From Figure 2 we observed an increase in the size of the $\mathrm{ZnO}$ seeds. The uniformity and alignment of the nanorods and nanostructures are related to the size and shape of the $\mathrm{ZnO}$ seed layers. 

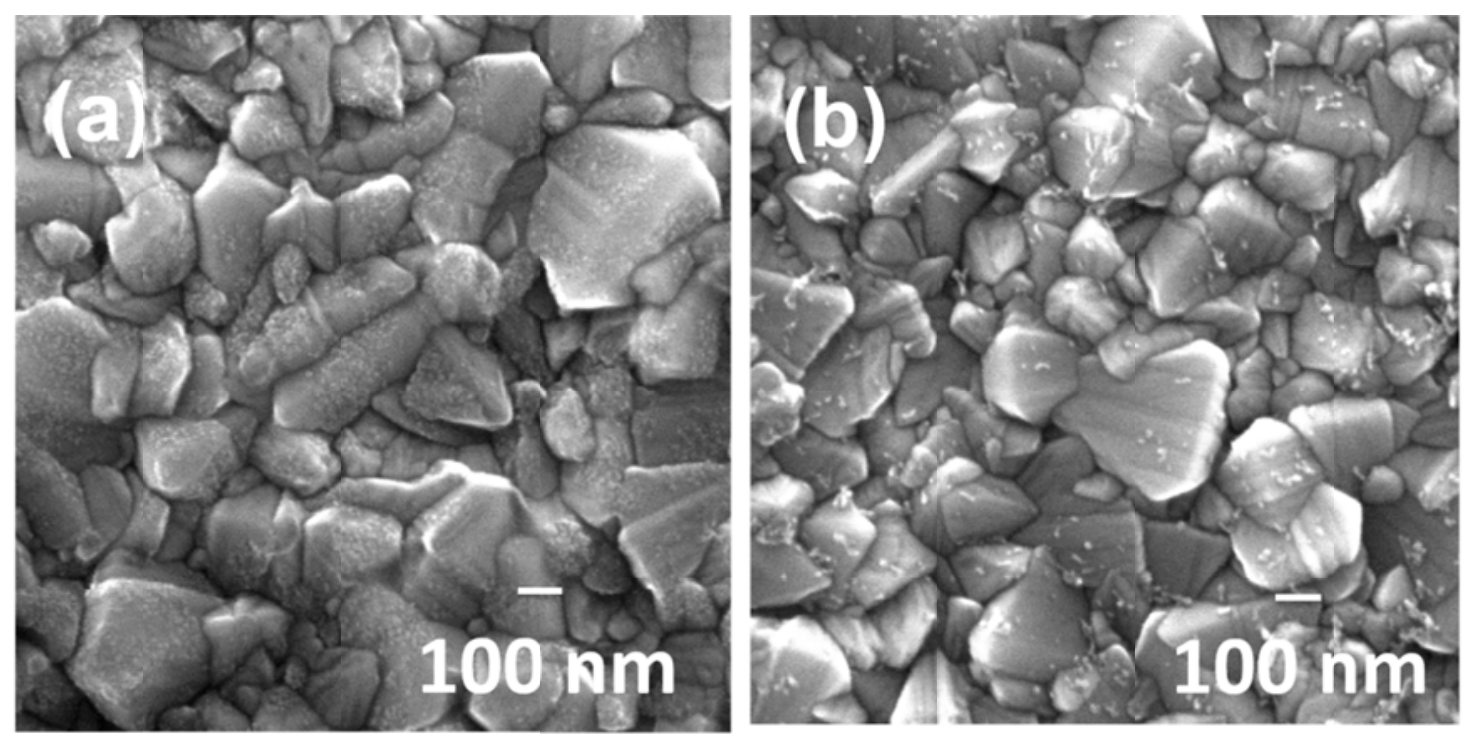

Figure 2. Scanning electron microscopy image of $\mathrm{ZnO}$ seeds on the FTO substrate with different concentrations of water in the seed precursor solution: (a) 0 and (b) $0.5 \mathrm{M}$

\subsection{Synthesis of $\mathrm{ZnO}$ fibers}

From the SEM image shown in Figure 3, it can be seen that the addition of the citric acid to the precursor solution effectively suppressed the growth of the $\mathrm{ZnO}$ in the (002) direction. When citric acid is added to the precursor solution the following reaction occurs [73]:

$$
\mathrm{C}_{6} \mathrm{H}_{5} \mathrm{O}_{7} \mathrm{H}_{3}+3 \mathrm{OH}^{-} \longrightarrow\left[\mathrm{C}_{6} \mathrm{H}_{5} \mathrm{O}_{7}\right]^{3-}+3 \mathrm{H}_{2} \mathrm{O}
$$

The precursor solution has an initial $\mathrm{pH}$ of 11 (measured), but citric acid pushes the $\mathrm{pH}$ below 10.4 inhibiting the nucleation of $\mathrm{ZnO}$. These conditions at a $90^{\circ} \mathrm{C}$ reaction temperature lead to the growth of the fibrous mat-like structure of the $\mathrm{ZnO}$. The sheets that comprise the fibers are amorphous and porous. The adsorption of negatively charged citrate anions on the positively charged $\mathrm{Zn}^{2+}$ ions in the (001) plane decreases the growth along the (001) direction [74]. Citrate also complexes $\mathrm{Zn}^{2+}$ in solution, decreasing its rate of hydrolysis [75]. The atom ratio of $\mathrm{Zn}: \mathrm{O}$ 
(0.9:1) in $\mathrm{ZnO}$ nanofibers, analyzed by energy dispersive $\mathrm{X}$-ray spectroscopy, is close to the stoichiometric $\mathrm{ZnO}$ ratio.

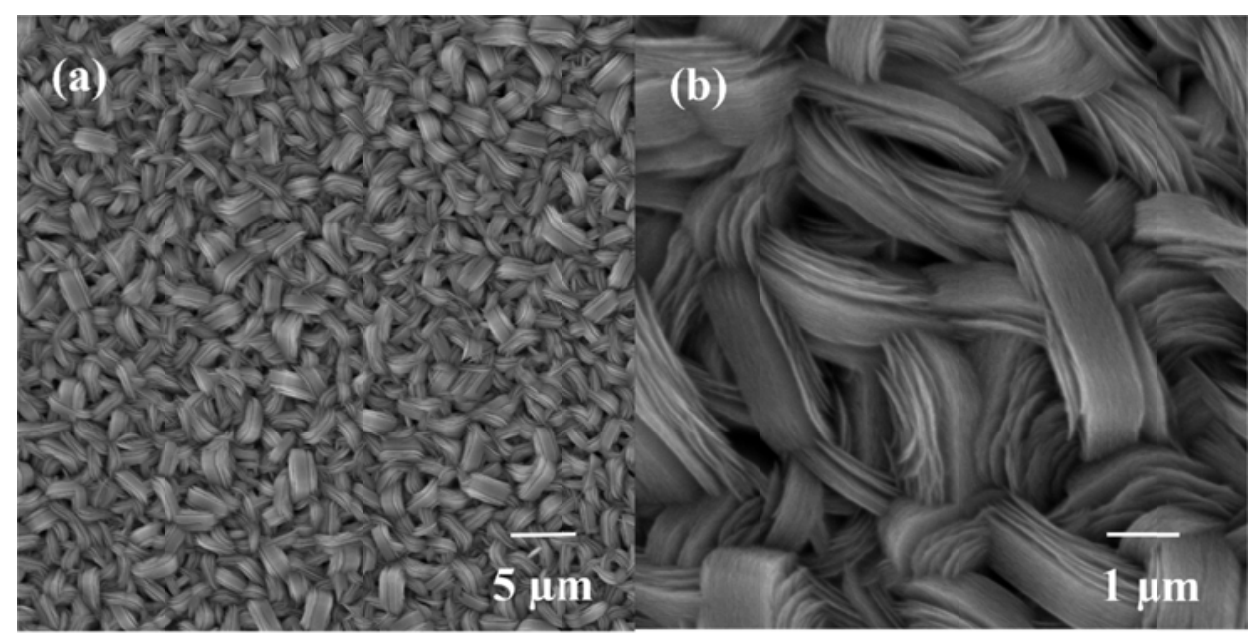

Figure 3. SEM image of the $\mathrm{ZnO}$ nanofibers.

\subsection{ZnO nanoflowers}

From Figure 4 we can observe the growth of the $\mathrm{ZnO}$ nanoflowers using chemical bath deposition using $0.35 \mathrm{M}$ ammonium hydroxide as an additive. The concentration of $\mathrm{OH}^{-}$is a critical factor in forming $\mathrm{ZnO}$ nanostructures. The nanoflowers are formed due to slow nucleation and growth via these reactions $[76,77]$ :

$$
\begin{aligned}
& \mathrm{Zn}^{2+}+2 \mathrm{OH}^{-} \rightarrow \mathrm{Zn}(\mathrm{OH})_{2}(1) \\
& \mathrm{Zn}(\mathrm{OH})_{2}+2 \mathrm{OH}^{-} \rightarrow \mathrm{Zn}(\mathrm{OH})_{4}^{2-}(2) \\
& \mathrm{Zn}(\mathrm{OH})_{4}{ }^{2-} \rightarrow \mathrm{ZnO}+2 \mathrm{H}_{2} \mathrm{O}+2 \mathrm{OH}^{-}
\end{aligned}
$$

We propose a possible mechanism for the growth of the flower like structures. In the presence of the $0.35 \mathrm{M}$ ammonium hydroxide at $90^{\circ} \mathrm{C}$, the rate of growth of nucleation of $\mathrm{ZnO}$ decreases. The seed crystals deposited by our method on the FTO glass are about $30 \mathrm{~nm}$ in diameter [72]. As the reaction begins, nuclei formed in the solution will aggregate around the seed crystals. $\mathrm{ZnO}$ growth proceeds omnidirectionally, leading to the growth of the petals of the nanoflower. The 
size of the petals is in the range of 500-600 nm. The petals are formed due to the erosion effect of the extra base as reported previously [78], leading to metastability where smaller crystals are thermodynamically more favorable than larger ones. But with further growth and Ostwald ripening over the course of the 24 hour reaction time, the petals become more uniform. No secondary nucleation on the nanoflower petals is observed. The size of the nanoflowers increased with the increase of the $\mathrm{Zn}^{2+}$ concentration from $0.125 \mathrm{M}$ to $0.25 \mathrm{M}$ in the precursor solution. The atom ratio of $\mathrm{Zn}: \mathrm{O}(0.93: 1)$ in $\mathrm{ZnO}$ nanoflowers, analyzed by energy dispersive $\mathrm{X}$-ray spectroscopy, matches the stoichiometric $\mathrm{ZnO}$ ratio.
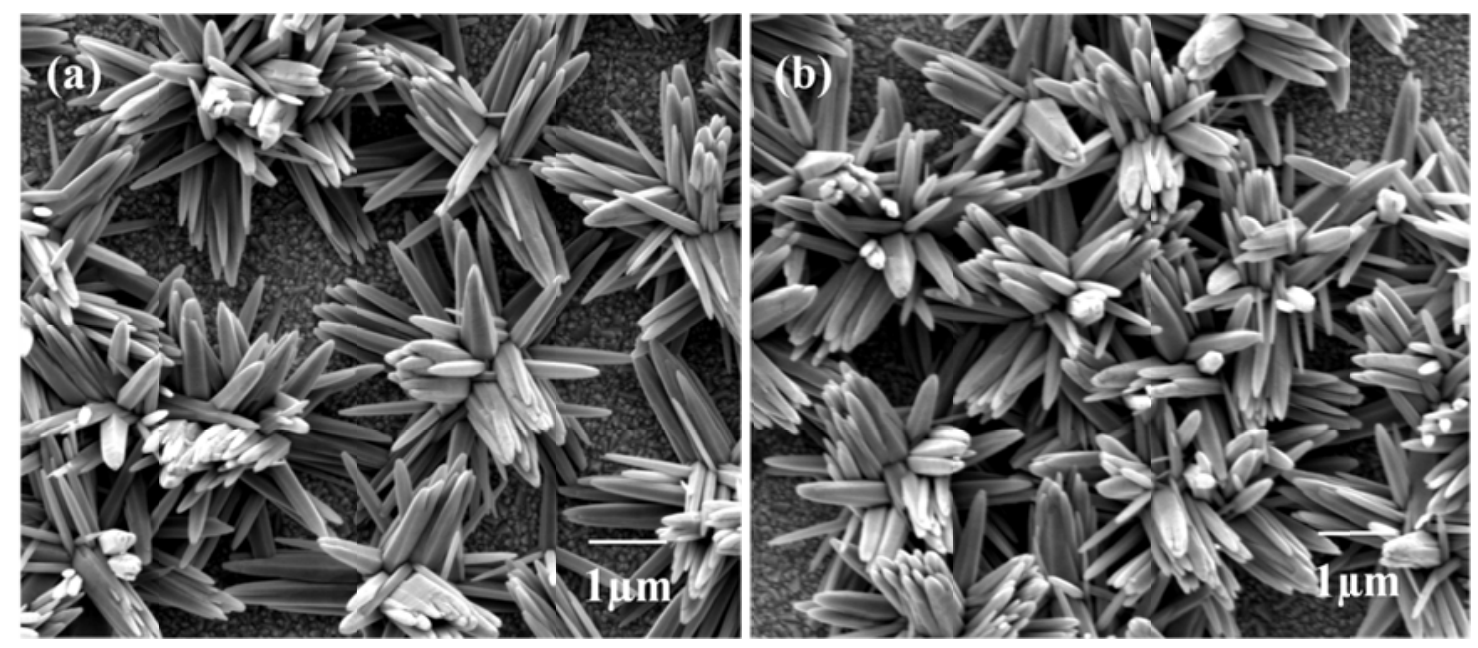

Figure 4. SEM image of $\mathrm{ZnO}$ nanoflowers (a) $0.25 \mathrm{M} \mathrm{Zn}^{2+}$ and (b) $0.125 \mathrm{M} \mathrm{Zn}^{2+}$.

\subsection{ZnO low-density nanorods}

Typical solution-grown $\mathrm{ZnO}$ nanorods are tightly packed; some control over the thickness of the rods is possible by varying the $\mathrm{Zn}$ precursor concentration, but control of the spacing between rods is difficult. Figure 5 shows large, more widely spaced $\mathrm{ZnO}$ nanorods that we synthesized by modifying the seed layer solution. The size of the seeds is increased by forced hydrolysis of the seed solution by adding DI water to the ethanolic seed precursor solution and heating at $80^{\circ} \mathrm{C}$. The $\mathrm{ZnO}$ nanorods shown were synthesized using $0.9 \mathrm{M}$ DI water. The decrease in the density of 
the nanorods is due to decease in the number of the grain boundaries with the increase in size of the seed particle [72]. The length and diameter of the nanorod are 6-7 $\mu \mathrm{m}$ and $0.7 \mu \mathrm{m}$ respectively. Due to the Ostwald ripening the $\mathrm{ZnO}$ top surface observed is perfectly round or less faceted hexagonal rather than the usual hexagonal wurzite structure of $\mathrm{ZnO}$. In general, the nanorod structure results because the growth rate of the $\mathrm{ZnO}$ is faster in the 0001 direction than other faces, and formation of long $\mathrm{ZnO}$ rods is observed at the expense of $\mathrm{ZnO}$ dissolving in the $(01 \overline{1} \overline{1}),(01 \overline{1} 0)$ and $(000 \overline{1})$ directions, assisted by adsorption of PEI and HMTA on the nonpolar faces of the $\mathrm{ZnO}$ leading to the growth along the c-axis [79].
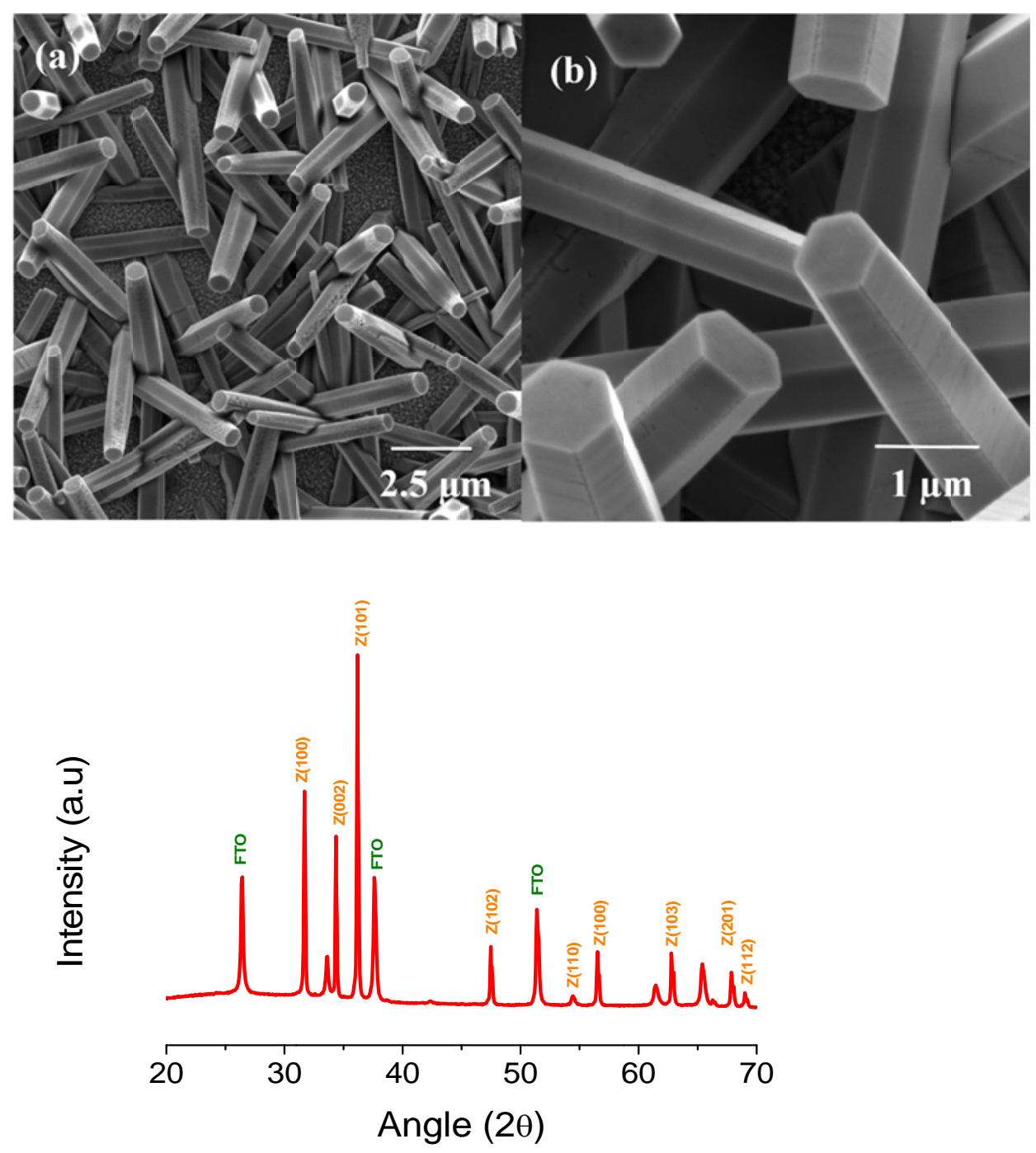
Figure 5. SEM image $(\mathrm{a}, \mathrm{b})$ and XRD pattern $(\mathrm{c})$ of the $\mathrm{ZnO}$ nanorods.

The XRD pattern in Figure 5(c) shows that the nanorods grew as crystalline $\mathrm{ZnO}$ with the hexagonal wurtzite structure [space group P63mc (186); $a=0.3249 \mathrm{~nm}, c=0.5206 \mathrm{~nm}$ ]. The data are in agreement with the Joint Committee on Powder Diffraction Standards (JCPDS) card for $\mathrm{ZnO}$ (JCPDS 070-8070). The prominence of the peak assigned to the (002) plane of $\mathrm{ZnO}$ is consistent with predominant $\mathrm{ZnO}$ growth along the $c$-axis, perpendicular to the substrate, giving the nanorod morphology. The atom ratio of $\mathrm{Zn}: \mathrm{O}(0.9: 1)$ in $\mathrm{ZnO}$ nanorods, analyzed by energy dispersive $\mathrm{X}$-ray spectroscopy, equals the stoichiometric $\mathrm{ZnO}$ ratio.

\subsection{ZnO nanotubes}

For $\mathrm{ZnO}$ crystals in the wurtize structure, the polar face (0001) is less stable than the nonpolar faces (1100), (1001) and (0110). Under the right conditions, this leads to more rapid growth from the (0001) face, giving the rod shape. But once the rate of dissolution exceeds the rate of formation, the polar (0001) face becomes vulnerable to etching [80]. This has also been associated with the high concentration of defects in the core compared to in the shell [81], which is reflected in the holes that can form inside some $\mathrm{ZnO}$ nanorods (see Figure 6). The result is that the core is etched out, leaving the shell intact [82], yielding $\mathrm{ZnO}$ nanotubes. The nanotubes shown in Figure 7 are about $5 \mu \mathrm{m}$ long and $\sim 300 \mathrm{~nm}$ in diameter. The measured wall thickness of the nanotube is $30-40 \mathrm{~nm}$. 


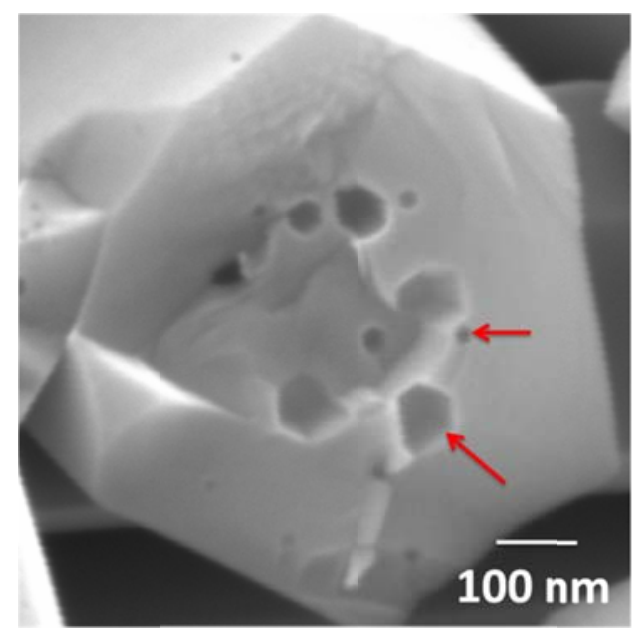

Figure 6. Broken $\mathrm{ZnO}$ nanorod (arrows indicate the defects)

The nanotubes are formed as the $\mathrm{pH}$ of the precursor changed due to the decrease in the geometric area of the deposition. Due to the high activity of the polar faces the etching of the $\mathrm{ZnO}$ nanorod occurred. Also the cooling of the samples during post deposition catalyzed the etching process as the decrease in the temperature increase the $\mathrm{OH}^{-}$concentration and $\mathrm{pH}$ [83].

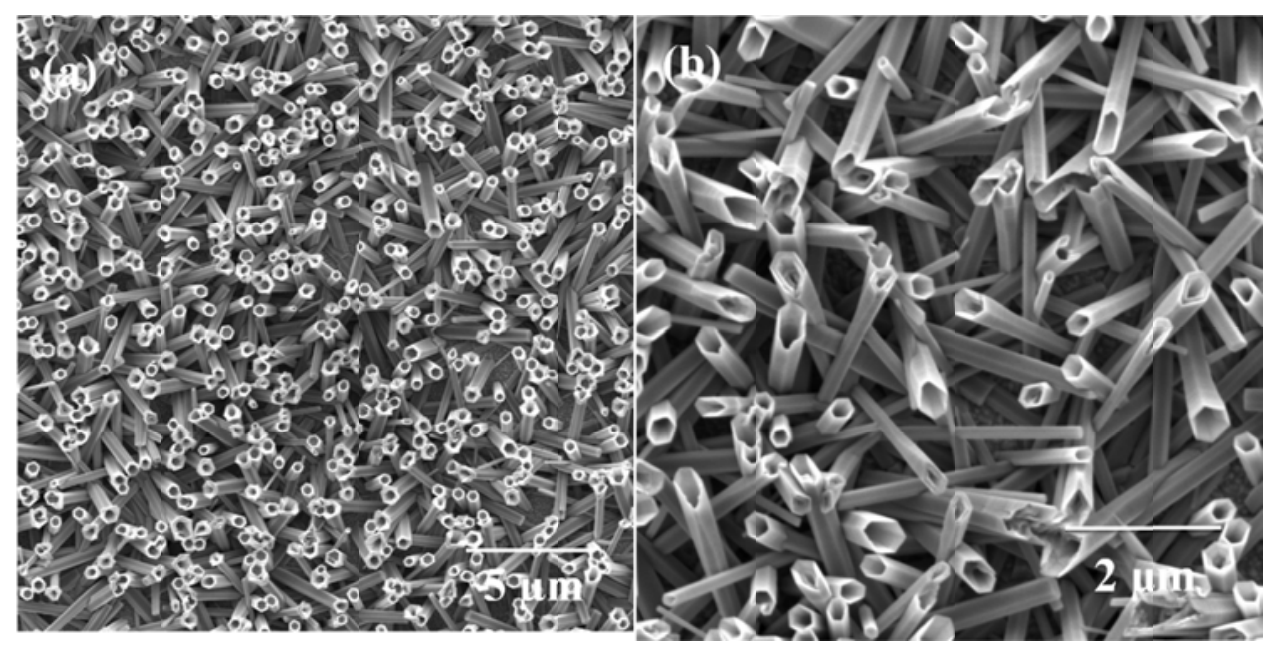

Figure 7. SEM image of the $\mathrm{ZnO}$ nanotubes.

The atom ratio of $\mathrm{Zn}: \mathrm{O}(0.97: 1) \mathrm{ZnO}$ nanotubes, analyzed by energy dispersive $\mathrm{X}$-ray spectroscopy, equals the stoichiometric $\mathrm{ZnO}$ ratio.

\subsection{ZnO nanoforest}


From the SEM image show in Figure 8, we can see the formation of the $\mathrm{ZnO}$ forest with $\mathrm{ZnO}$ nanowires. The length and diameter of the nanowires are $4 \mu \mathrm{m}$ and $28 \mathrm{~nm}$ respectively. Due to the low concentration of the $\mathrm{Zn}^{2+}$ and high concentration of the PEI the formation of the thin $\mathrm{ZnO}$ nanowires was observed.

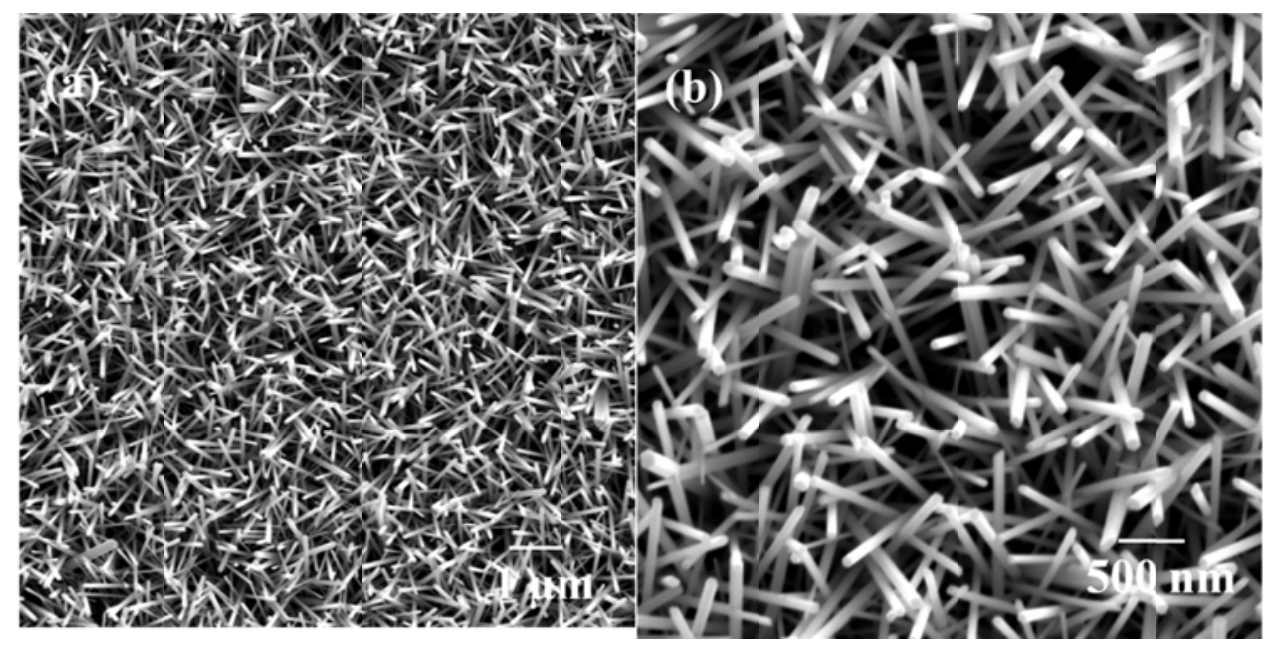

(c)

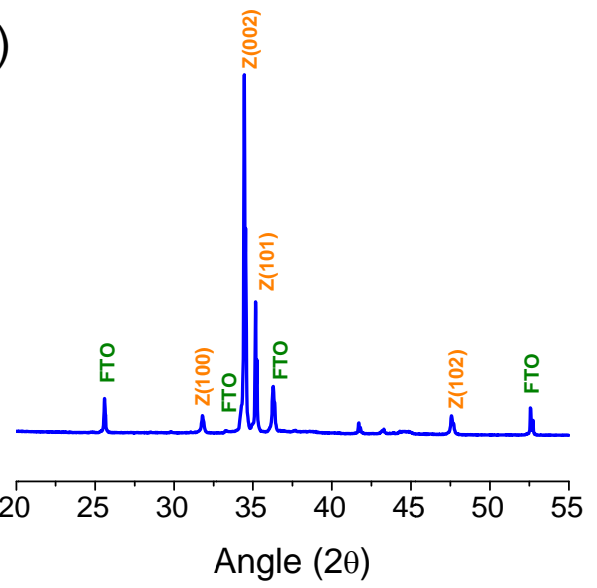

Figure 8. SEM image of the $\mathrm{ZnO}$ nanoforest $(\mathrm{a}, \mathrm{b})$ and $(\mathrm{c}) \mathrm{XRD}$ pattern of $\mathrm{ZnO}$ nanoforest.

The XRD pattern in Figure 8(c) show that the nanorods grew as crystalline $\mathrm{ZnO}$ with the hexagonal wurtzite structure [space group P63mc (186); $a=0.3249 \mathrm{~nm}, c=0.5206 \mathrm{~nm}$ ]. The data are in agreement with the Joint Committee on Powder Diffraction Standards (JCPDS) card for $\mathrm{ZnO}$ (JCPDS 070-8070). The intensity of the peak assigned to the (002) plane of $\mathrm{ZnO}$ is 
consistent with predominant $\mathrm{ZnO}$ growth along the $c$-axis, perpendicular to the substrate, giving the nanowire morphology.

The atom ratio of $\mathrm{Zn}: \mathrm{O}(0.95: 1)$ in $\mathrm{ZnO}$ nanowires, analyzed by energy dispersive $\mathrm{X}$-ray spectroscopy, equals the stoichiometric $\mathrm{ZnO}$ ratio.

\subsection{ZnO nanotree structures}

The nanotree structures (shown in Figure 9) are formed due to the high concentration $(0.7 \mathrm{M})$ of ammonium hydroxide. In the presence of the ammonium hydroxide the reaction mechanism will change, leading to the formation of the zinc ammonium complex and $\mathrm{ZnO}$. The reactions involved in the formation of $\mathrm{ZnO}$ in the presence of ammonium hydroxide are:

$$
\begin{gathered}
\mathrm{NH}_{3}+\mathrm{H}_{2} \mathrm{O} \leftrightarrow \mathrm{NH}_{4}^{+}+\mathrm{OH}^{-} \\
\mathrm{Zn}^{2+}+4 \mathrm{NH}_{3} \rightarrow \mathrm{Zn}\left(\mathrm{NH}_{3}\right)_{4}^{2+} \\
\mathrm{Zn}\left(\mathrm{NH}_{3}\right)_{4}^{+}+2 \mathrm{OH}^{-} \rightarrow \mathrm{ZnO}+\mathrm{NH}_{3}+\mathrm{H}_{2} \mathrm{O}
\end{gathered}
$$

The addition of $\mathrm{NH}_{3}$ decreases the homogenous nucleation in the solution. This leaves abundant $\mathrm{Zn}$ species available for the heterogenous nucleation of $\mathrm{ZnO}$ leading to the formation of the tree like structures nucleating from the base nanorod. Due to the formation of the $\mathrm{Zn}\left(\mathrm{NH}_{3}\right)_{4}{ }^{2+}$, continous supply of $\mathrm{Zn}^{2+}$ leads to renucleation of the $\mathrm{ZnO}$ surface leading to the formation of the branches on the $\mathrm{ZnO}$ nanorod. The atom ratio of $\mathrm{Zn}: \mathrm{O}(0.9: 1)$ in $\mathrm{ZnO}$ nanotree, analyzed by energy dispersive $\mathrm{X}$-ray spectroscopy, equals the stoichiometric $\mathrm{ZnO}$ ratio. 


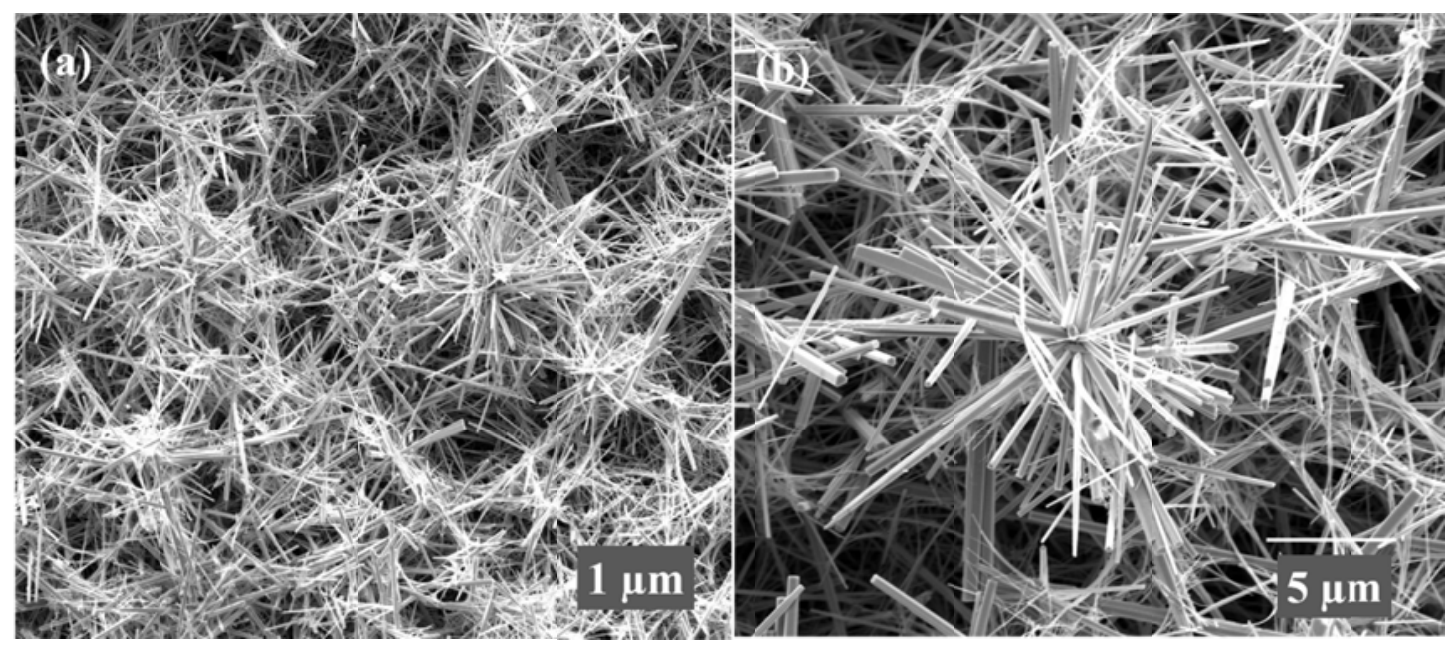

Figure 9. SEM image of the $\mathrm{ZnO}$ nanotree structure.

\subsection{ZnO nanopencil rods}

From the Figure 10 formation of $\mathrm{ZnO}$ nanopencil rods are formed after introducing fresh precursor solution for every 4 hours with the total growth time of 16 hours. From the previous growth models we observed the growth of the $\mathrm{ZnO}$ is fastest in the (0001) direction [84]. With replenished precursor, however, the accelerated growth of the (10 $\overline{1} 1)$ polar planes shapes the crystal morphology. Due to the electrostatic interactions between the polar surface and the ions, the $(10 \overline{1} 1)$ planes with high Miller index and low surface energy become the preferred growth direction leading to the formation of the pencil shaped $\mathrm{ZnO}$ nanostructures [85]. The atom ratio of $\mathrm{Zn}: \mathrm{O}(0.99: 1)$ in $\mathrm{ZnO}$ nanopencils, analyzed by energy dispersive X-ray spectroscopy, equals the stoichiometric $\mathrm{ZnO}$ ratio. 


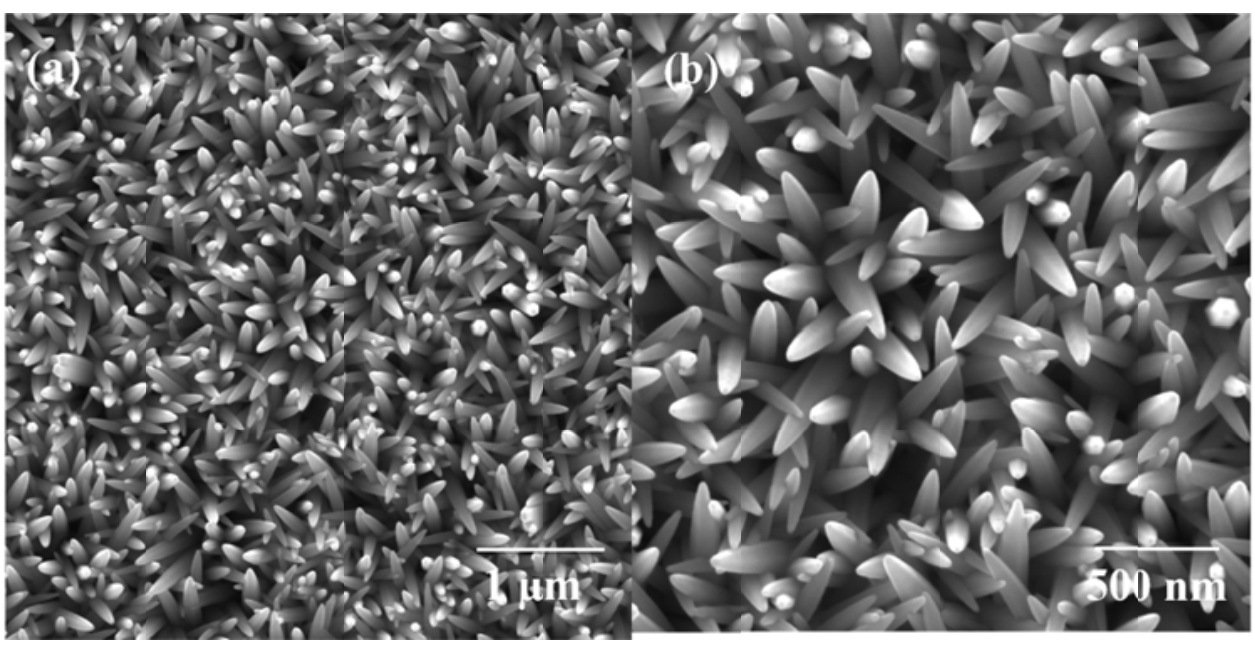

Figure 10. SEM image of pencil shaped nanorods

\subsection{ZnO nanorod balls}

$\mathrm{ZnO}$ nanorod balls (shown in Figure 11) are formed due to aggregation of the nuclei in the seed solution and deposited on the surface of the FTO substrate. Each aggregated seed acts as an individual nucleation site. The renucleation and subsequent steps of the growth process are shown in Figure 11(b). In stage 1 the precipitates of the homogenous nucleation form two rods joined together into a twinned nanorod. In the stage $2 \mathrm{ZnO}$ nanorods grow from the defect site of the primary structure at the interface with the FTO substrate. In the stage 3 the nanorods grow at the joint section of the twinned nanorods. In the stage 4 the subsequent nanorods grow in all the directions leading to the formation of a 3-D ball shaped nanorod structure [86]. The individual nanorods have similar diameter and length leading to a perfectly round 3-D $\mathrm{ZnO}$ nanostructure. Due to the larger seed size used for the seed layer for the growth of the 3-D ball nanostructures, the supersaturation degree is decreased suppressing homogenous nucleation and initiating heterogeneous nucleation. The heterogeneous nucleation leads to increase in growth rate leading to $20 \mu \mathrm{m}$ diameter 3-D $\mathrm{ZnO}$ nanorod balls. 
During the growth process, Ostwald ripening, in which smaller crystals are consumed by the larger crystals, results in the formation of the larger 3-D structures and the large spacing between them [87]. The formation of the 3-D structures reduces the total surface energy of the system becoming energetically favorable [88]. The atom ratio of $\mathrm{Zn}: \mathrm{O}(0.9: 1)$ in $\mathrm{ZnO}$ nanoballs, analyzed by energy dispersive $\mathrm{X}$-ray spectroscopy, equals the stoichiometric $\mathrm{ZnO}$ ratio.
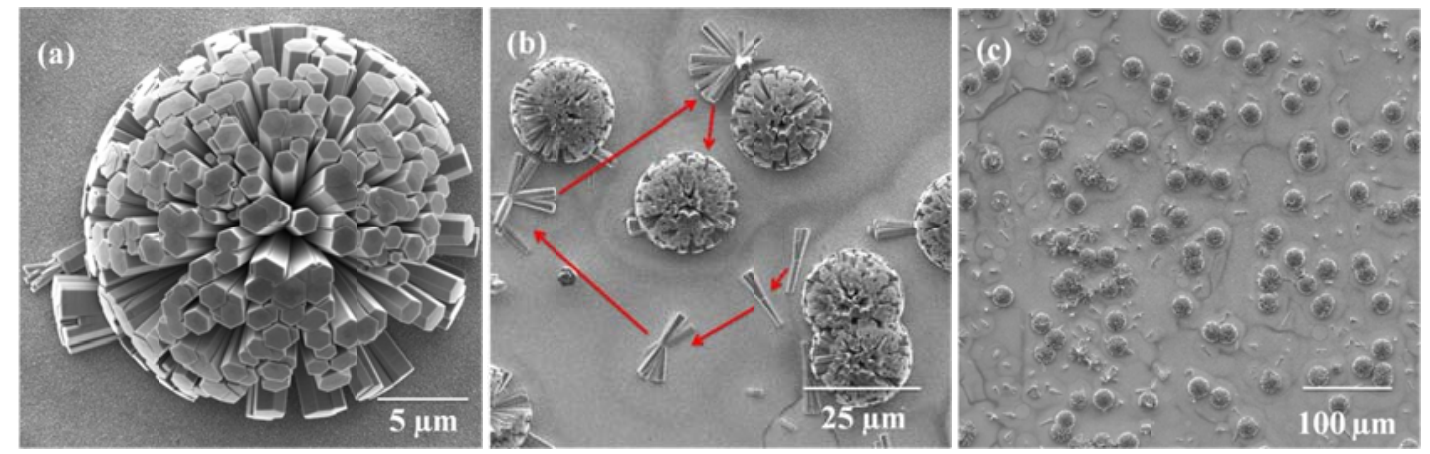

Figure 11. SEM image of the $\mathrm{ZnO}$ balls

\subsection{ZnO ellipsoidal shaped micro particles}

From Figure 12 the formation of the nut shaped microparticles were observed. The ellipsoidal particles are monodisperse in size and around $1 \mu \mathrm{m}$ in length. Most of the microparticles aggregate and partially fuse together. The external structure of the microsphere is rough as shown in Figure 12b. During the chemical bath reaction $\mathrm{Zn}(\mathrm{OH})_{2}$ and $\mathrm{Zn}(\mathrm{OH})_{4}^{2-}$ are formed. Rapid deposition of $\mathrm{Zn}(\mathrm{OH})_{4}^{2-}$ causes the $(01 \overline{1} 0)$ face to grow faster than the $(01 \overline{1} 1)$ face, resulting in extrusion of the $(01 \overline{1} 0)$ planes, giving rise to the ellipsoidal particle shape [89]. These prisms like ellipsoidal structures join along the major axis as show in Figure 12b. The atom ratio of $\mathrm{Zn}: \mathrm{O}(0.99: 1)$ in $\mathrm{ZnO}$ ellipsoidal particles, analyzed by energy dispersive $\mathrm{X}$-ray spectroscopy, equals the stoichiometric $\mathrm{ZnO}$ ratio. 

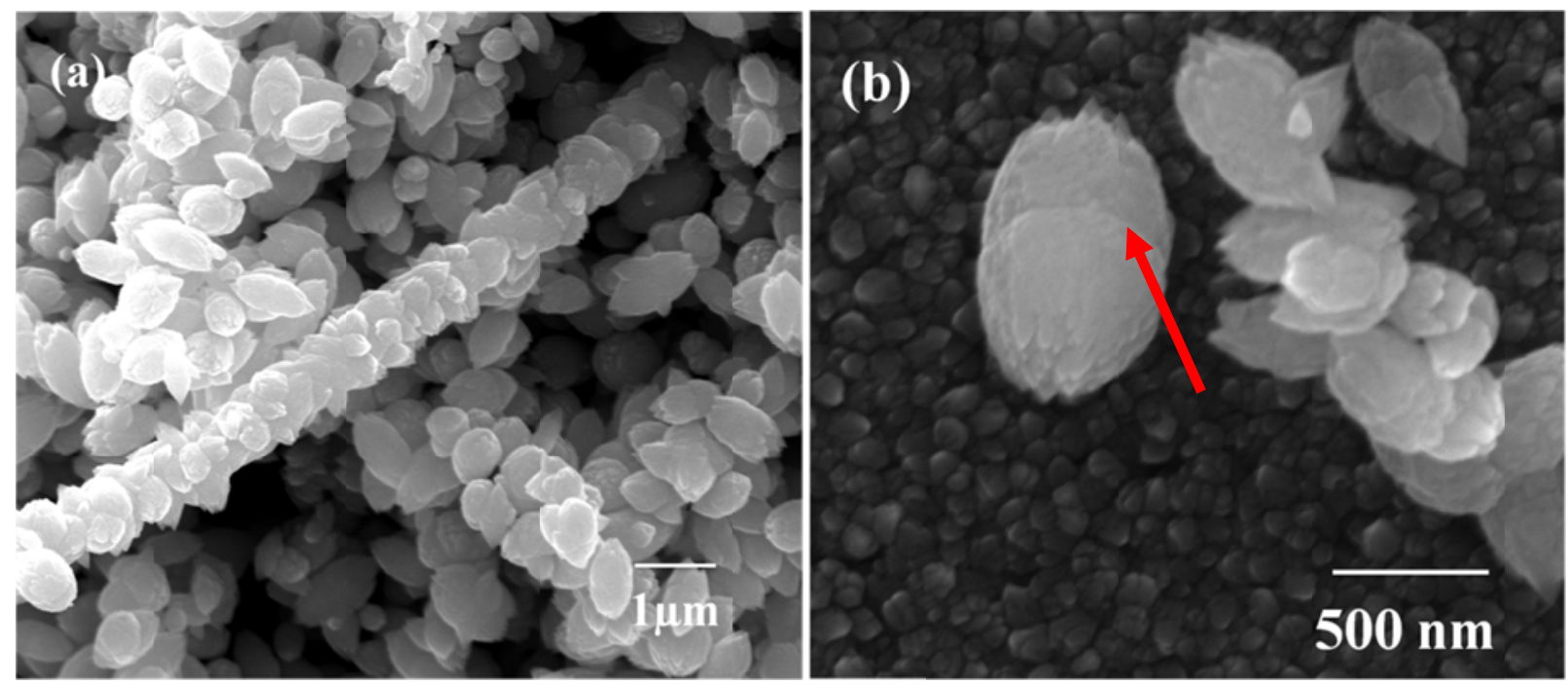

Figure 12. SEM image of the $\mathrm{ZnO}$ microparticles at two magnifications

\subsection{ZnO cauliflowers}

From the SEM image Figure 13 the formation of $\mathrm{ZnO}$ cauliflower structure is observed. The cauliflower shaped $\mathrm{ZnO}$ has larger surface to volume ratio than the other $\mathrm{ZnO}$ nanostructures. The $\mathrm{ZnO}$ cauliflowers are formed due to the high erosion rate of the $\mathrm{ZnO}$ caused by the higher concentration of $\mathrm{OH}^{-}$formed from the $0.25 \mathrm{M}$ ammonium hydroxide added to the precursor solution ( $\mathrm{pH}>11)$. In this condition PEI acts as a capping agent and ammonium hydroxide is the structure directing agent. Due to the high concentration of ammonium hydroxide the erosion occurs simultaneously with growth. PEI capping agent covers the growth layers leads to the lower aspect ratio and formation of the cauliflower-like $\mathrm{ZnO}$ assembled by cone shaped nanoflowers. The atom ratio of $\mathrm{Zn}: \mathrm{O}(0.87: 1)$ in $\mathrm{ZnO}$ cauliflowers, analyzed by energy dispersive $\mathrm{X}$-ray spectroscopy, equals the stoichiometric $\mathrm{ZnO}$ ratio. 

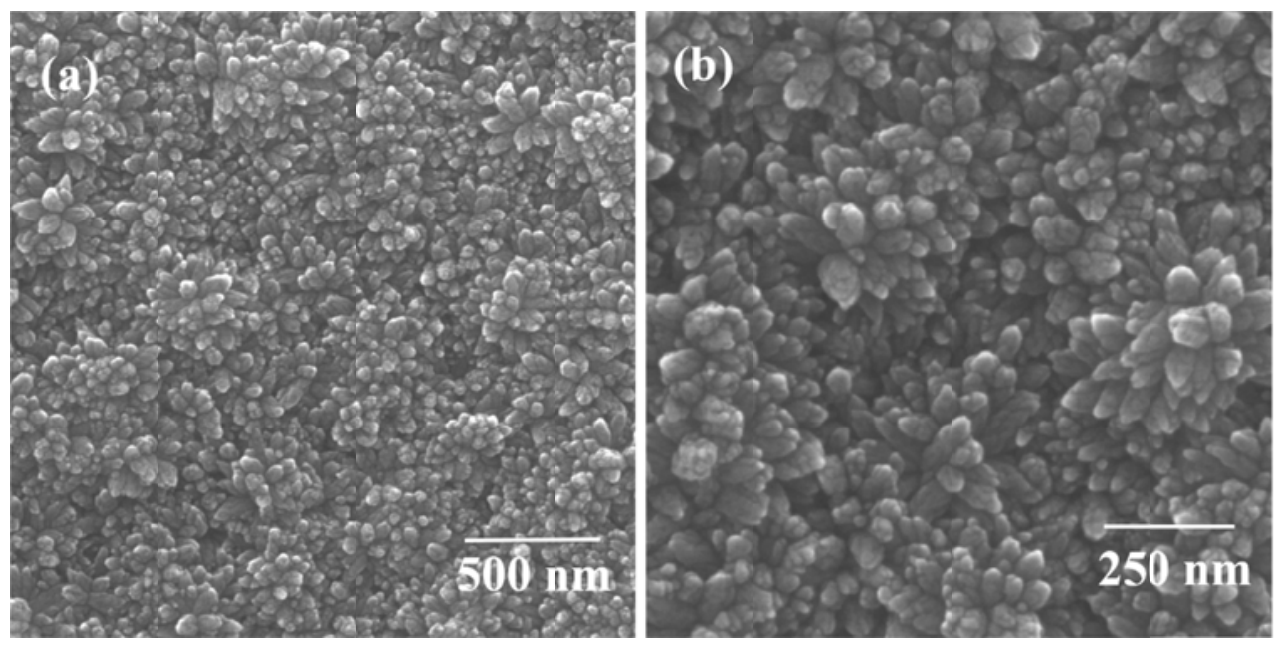

Figure 13. SEM image of the $\mathrm{ZnO}$ cauliflowers.

\subsection{ZnO platelets}

From the Figure 14 formation of the nanoplatelets is observed by using $150 \mathrm{mM}$ zinc nitrate hexahydrate and hexamethylenetetramine. The diameter of the platelets was $3 \mu \mathrm{m}$. Polyethyleneamine (PEI) was not added to the precursor solution. PEI increases the aspect ratio of $\mathrm{ZnO}$ rods by adsorbing on the lateral faces of the $\mathrm{ZnO}$ hexagonal structure and preventing lateral growth $[90,91]$. Lacking PEI but containing a high concentration of the $\mathrm{Zn}$ species, which is higher than the critical concentration for the nucleation of (0001) and (10 $\overline{1} 0)$ plane, lateral growth proceeds rapidly, leading to the platelet structure. The formation of platelets is observed at concentrations above $100 \mathrm{mM}$ of the $\mathrm{Zn}$ species using a modified seed layer solution. The atom ratio of $\mathrm{Zn}: \mathrm{O}(0.99: 1)$ in $\mathrm{ZnO}$ platelets, analyzed by energy dispersive X-ray spectroscopy, equals the stoichiometric $\mathrm{ZnO}$ ratio. 


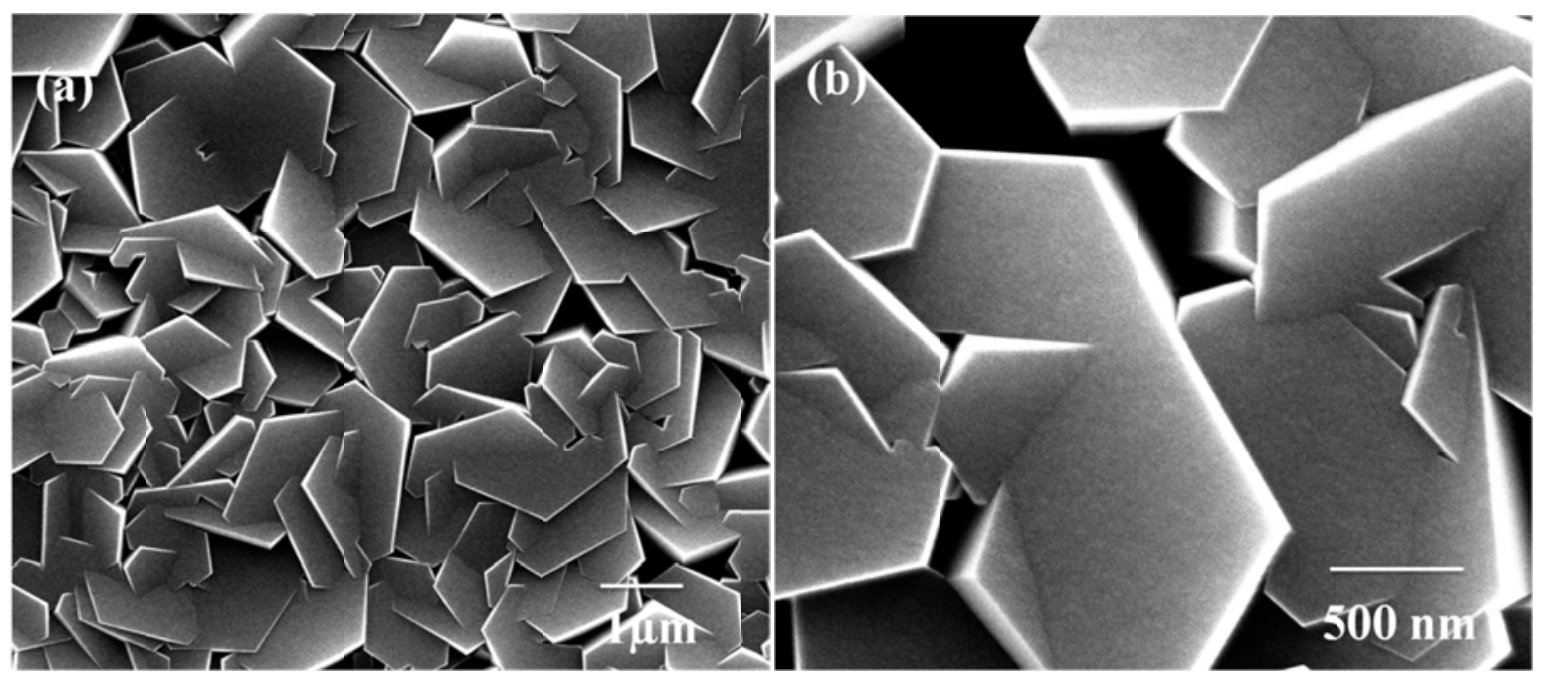

Figure 14. SEM images of $\mathrm{ZnO}$ platelets at two different magnifications

\section{Conclusion}

A wide variety of $\mathrm{ZnO}$ nanostructures from nanorods to nanoballs are synthesized by using chemical bath deposition. The chocie of additives and their concentrations direct the growth of $\mathrm{ZnO}$ toward different types of structures. Besides its effects on the surface-to-volume ratio, the morphology change can result in changes in the number of defects, optical properties, stability, electron transport, and other electronic properties. The varied structures allow for numerous applications in different device types.

\section{Acknowledgements}

This material is based on work supported by the National Science Foundation under Grant No. CBET-1332022. The authors thank the University of Connecticut Center for Clean Energy Engineering for the usage of the XRD and SEM. 


\section{References}

[1] J. Joo, B.Y. Chow, M. Prakash, E.S. Boyden, J.M. Jacobson, Nat Mater 10 (2011) 596-601.

[2] X. Sun, Q. Li, J. Jiang, Y. Mao, Nanoscale 6 (2014) 8769-8780.

[3] S.C. Warren, K. Voïtchovsky, H. Dotan, C.M. Leroy, M. Cornuz, F. Stellacci, C. Hébert, A. Rothschild, M. Grätzel, Nat Mater 12 (2013) 842-849.

[4] F. Fleischhaker, V. Wloka, I. Hennig, J. Mater. Chem. 20 (2010) 6622-6625.

[5] D.-J. Kim, J.-H. Hyung, D.-W. Seo, D.-I. Suh, S.-K. Lee, J. Electron. Mater. 39 (2010) 563-567.

[6] S. Bai, W. Wu, Y. Qin, N. Cui, D.J. Bayerl, X. Wang, Adv. Funct. Mater. 21 (2011) 4464-4469.

[7] M. Chen, Z. Wang, D. Han, F. Gu, G. Guo, Sens. Actuators, B 157 (2011) 565-574.

[8] J. Chang, M. Ahmad, W. Wlodarski, E. Waclawik, Sensors 13 (2013) 8445-8460.

[9] H. Zhang, J. Sun, V.L. Dagle, B. Halevi, A.K. Datye, Y. Wang, ACS Catalysis 4 (2014) 2379-2386.

[10] H. Lorenz, M. Friedrich, M. Armbrüster, B. Klötzer, S. Penner, J. Catal. 297 (2013) 151-154.

[11] T. Reimer, I. Paulowicz, R. Röder, S. Kaps, O. Lupan, S. Chemnitz, W. Benecke, C. Ronning, R. Adelung, Y.K. Mishra, ACS Appl. Mater. Interfaces 6 (2014) 7806-7815.

[12] J.-J. Dong, H.-Y. Hao, J. Xing, Z.-J. Fan, Z.-L. Zhang, Nanoscale Res. Lett. 9 (2014) 630-630.

[13] S. Xu, C. Xu, Y. Liu, Y. Hu, R. Yang, Q. Yang, J.-H. Ryou, H.J. Kim, Z. Lochner, S. Choi, R. Dupuis, Z.L. Wang, Adv. Mater. 22 (2010) 4749-4753.

[14] M. Abbasi, Z. Ibupoto, M. Hussain, O. Nur, M. Willander, Nanoscale Res. Lett. 8 (2013) 320.

[15] S.J. Pearton, F. Ren, Curr. Opin. Chem. Engg. 3 (2014) 51-55.

[16] X. Wang, J. Zhou, J. Song, J. Liu, N. Xu, Z.L. Wang, Nano Lett. 6 (2006) 2768-2772.

[17] B. Kumar, S.-W. Kim, Nano Energy 1 (2012) 342-355.

[18] E. Broitman, M.Y. Soomro, J. Lu, M. Willander, L. Hultman, PCCP 15 (2013) 11113-11118.

[19] Z.L. Wang, Nano Today 5 (2010) 540-552.

[20] E. Lee, J. Park, M. Yim, Y. Kim, G. Yoon, Appl. Phys. Lett. 106 (2015) 023901.

[21] M.-L. Zhang, F. Jin, M.-L. Zheng, J. Liu, Z.-S. Zhao, X.-M. Duan, RSC Advances 4 (2014) 10462-10466.

[22] V. Manthina, J.P. Correa Baena, G. Liu, A.G. Agrios, J. Phys. Chem. C 116 (2012) 23864-23870.

[23] M. Law, L.E. Greene, J.C. Johnson, R. Saykally, P. Yang, Nat Mater 4 (2005) 455-459.

[24] Z.A. Lewicka, W.W. Yu, B.L. Oliva, E.Q. Contreras, V.L. Colvin, J. Photochem. Photobiol., A 263 (2013) 24-33.

[25] A. SenGupta, I. Lin, Google Patents, 2006.

[26] J. Huang, S. Chu, J. Kong, L. Zhang, C.M. Schwarz, G. Wang, L. Chernyak, Z. Chen, J. Liu, Adv. Opt. Mater. 1 (2013) 179-185.

[27] H.K. Liang, S.F. Yu, H.Y. Yang, Appl. Phys. Lett. 96 (2010) 101116.

[28] M.T.Z. Myint, N.S. Kumar, G.L. Hornyak, J. Dutta, Appl. Surf. Sci. 264 (2013) 344-348.

[29] L. Yao, M. Zheng, C. Li, L. Ma, W. Shen, Nanoscale Res. Lett. 7 (2012) 216.

[30] C.-H. Lin, S. Polisetty, L. O’Brien, A. Baruth, M.A. Hillmyer, C. Leighton, W.L. Gladfelter, ACS Nano (2015).

[31] Q. Li, T.-T. Shen, Y.-L. Cao, K. Zhang, S.-S. Yan, Y.-F. Tian, S.-S. Kang, M.-W. Zhao, Y.-Y. Dai, Y.-X. Chen, G.-L. Liu, L.-M. Mei, X.-L. Wang, P. Grünberg, Sci. Rep. 4 (2014).

[32] H. Masoumbaigi, A. Rezaee, H. Hosseini, S. Hashemi, Desalin. Water Treat. (2014) 1-6.

[33] Y.K. Mishra, R. Adelung, C. Röhl, D. Shukla, F. Spors, V. Tiwari, Antiviral Res. 92 (2011) 305-312.

[34] Y.K. Mishra, S. Kaps, A. Schuchardt, I. Paulowicz, X. Jin, D. Gedamu, S. Wille, O. Lupan, R. Adelung, Kona Powder Part. J. 31 (2014) 92-110.

[35] R. Wahab, S. Dwivedi, A. Umar, S. Singh, I.H. Hwang, H.-S. Shin, J. Musarrat, A.A. Al-Khedhairy, Y.-S. Kim, J. Biomed. Nanotechnol. 9 (2013) 441-449.

[36] W.S. W. Kosanlavit, and R. Kosanlavit, Int. J. Chem. Eng. Appl. 6 (2015) 125-129. 
[37] Y.-J. Kim, W.W. Lee, I.-C. Choi, B.-G. Yoo, S.M. Han, H.-G. Park, W.I. Park, J.-i. Jang, Acta Mater. 61 (2013) 7180-7188.

[38] Y. Ying, T. Song, H. Huang, X. Peng, Appl. Phys. A 110 (2013) 351-359.

[39] V. Cauda, D. Pugliese, N. Garino, A. Sacco, S. Bianco, F. Bella, A. Lamberti, C. Gerbaldi, Energy 65 (2014) 639-646.

[40] X. Sun, Q. Li, Y. Lu, Y. Mao, Chem. Commun. 49 (2013) 4456-4458.

[41] L. Xiao, D. Mei, M. Cao, D. Qu, B. Deng, J. Alloys Compd. 627 (2015) 455-462.

[42] Ü. Özgür, Y.I. Alivov, C. Liu, A. Teke, M.A. Reshchikov, S. Doğan, V. Avrutin, S.-J. Cho, H. Morkoç, J. Appl. Phys. 98 (2005) 041301.

[43] C.-Y. Chen, J.R.D. Retamal, I.W. Wu, D.-H. Lien, M.-W. Chen, Y. Ding, Y.-L. Chueh, C.-I. Wu, J.-H. He, ACS Nano 6 (2012) 9366-9372.

[44] B. Wei, K. Zheng, Y. Ji, Y. Zhang, Z. Zhang, X. Han, Nano Lett. 12 (2012) 4595-4599.

[45] Y. Kinemuchi, M. Mikami, K. Kobayashi, K. Watari, Y. Hotta, J. Electron. Mater. 39 (2010) 2059-2063.

[46] S.A. Vanalakar, S.S. Mali, R.C. Pawar, N.L. Tarwal, A.V. Moholkar, J.H. Kim, P.S. Patil, J. Appl. Phys. 112 (2012) 044302-044307.

[47] D.Q. Yun, X.Y. Xia, S. Zhang, Z.Q. Bian, R.H. Liu, C.H. Huang, Chem. Phys. Lett. 516 (2011) 92-95.

[48] J.S. Wang, K.M. Lakin, Appl. Phys. Lett. 42 (1983) 352-354.

[49] Y. Cui, A. Yu, H. Pan, X. Zhou, W. Ding, CrystEngComm 14 (2012) 7355-7359.

[50] S.-H. Yu, L.R. MacGillivray, C. Janiak, CrystEngComm 14 (2012) 7531-7534.

[51] X. Zhang, J. Qin, Y. Xue, P. Yu, B. Zhang, L. Wang, R. Liu, Sci. Rep. 4 (2014).

[52] Y.K. Mishra, G. Modi, V. Cretu, V. Postica, O. Lupan, T. Reimer, I. Paulowicz, V. Hrkac, W. Benecke, L. Kienle, R. Adelung, ACS Appl. Mater. Interfaces 7 (2015) 14303-14316.

[53] S.P. Mucur, T.A. Tumay, S. Birdoğan, S.E. San, E. Tekin, Nano-Structures \& Nano-Objects 1 (2015) 714.

[54] N. Noor, L. Lucera, T. Capuano, V. Manthina, A.G. Agrios, H. Silva, A. Gokirmak, Beilstein J. Nanotechnol. 6 (2015) 2463-2469.

[55] P. O'Brien, T. Saeed, J. Knowles, J. Mater. Chem. 6 (1996).

[56] L. Vayssieres, K. Keis, A. Hagfeldt, S.-E. Lindquist, Chem. Mater. 13 (2001) 4395-4398.

[57] T. Yoshida, M. Tochimoto, D. Schlettwein, D. Wöhrle, T. Sugiura, H. Minoura, Chem. Mater. 11 (1999) 2657-2667.

[58] B. O'Regan, V. Sklover, M. Gratzel, J. Electrochem. Soc. 148 (2001) C498-C505.

[59] L. Xu, Q. Liao, J. Zhang, X. Ai, D. Xu, J. Phys. Chem. C 111 (2007) 4549-4552.

[60] M.H. Huang, Y. Wu, H. Feick, N. Tran, E. Weber, P. Yang, Adv. Mater. 13 (2001) 113-116.

[61] R.R. Bacsa, J. Dexpert-Ghys, M. Verelst, A. Falqui, B. Machado, W.S. Bacsa, P. Chen, S.M. Zakeeruddin, M. Graetzel, P. Serp, Adv. Funct. Mater. 19 (2009) 875-886.

[62] J. Jie, G. Wang, Y. Chen, X. Han, Q. Wang, B. Xu, J.G. Hou, Appl. Phys. Lett. 86 (2005) 031909031903.

[63] H. Zeng, W. Cai, P. Liu, X. Xu, H. Zhou, C. Klingshirn, H. Kalt, ACS Nano 2 (2008) 1661-1670.

[64] H. Zeng, G. Duan, Y. Li, S. Yang, X. Xu, W. Cai, Adv. Funct. Mater. 20 (2010) 561-572.

[65] S. Jebril, H. Kuhlmann, S. Müller, C. Ronning, L. Kienle, V. Duppel, Y.K. Mishra, R. Adelung, Crystal Growth \& Design 10 (2010) 2842-2846.

[66] Y.K. Mishra, S. Mohapatra, R. Singhal, D.K. Avasthi, D.C. Agarwal, S.B. Ogale, Appl. Phys. Lett. 92 (2008) 043107.

[67] H. Peng, Y. Fangli, B. Liuyang, L. Jinlin, C. Yunfa, J. Phys. Chem. C 111 (2007) 194-200.

[68] K.C. Patil, S.T. Aruna, T. Mimani, Curr. Opin. Solid State Mater. Sci. 6 (2002) 507-512.

[69] I. Bilecka, M. Niederberger, Nanoscale 2 (2010) 1358-1374.

[70] D. Bekermann, A. Gasparotto, D. Barreca, L. Bovo, A. Devi, R.A. Fischer, O.I. Lebedev, C. Maccato, E. Tondello, G. Van Tendeloo, Cryst. Growth Des. 10 (2010) 2011-2018. 
[71] L. Spanhel, M.A. Anderson, J. Am. Chem. Soc. 113 (1991) 2826-2833.

[72] V. Manthina, T. Patel, A.G. Agrios, J. Am. Ceram. Soc. 97 (2014) 1028-1034.

[73] S. Cho, J.-W. Jang, S.-H. Jung, B.R. Lee, E. Oh, K.-H. Lee, Langmuir 25 (2009) 3825-3831.

[74] S. Cho, J.-W. Jang, A. Jung, S.-H. Lee, J. Lee, J.S. Lee, K.-H. Lee, Langmuir 27 (2010) 371-378.

[75] L. Jia, W. Cai, H. Wang, H. Zeng, Cryst. Growth Des. 8 (2008) 4367-4371.

[76] R. Shi, P. Yang, J. Wang, A. Zhang, Y. Zhu, Y. Cao, Q. Ma, CrystEngComm 14 (2012) 5996-6003.

[77] S. Ashoka, G. Nagaraju, C.N. Tharamani, G.T. Chandrappa, Mater. Lett. 63 (2009) 873-876.

[78] C. Yan, D. Xue, J. Phys. Chem. B 110 (2006) 11076-11080.

[79] V. Strano, R.G. Urso, M. Scuderi, K.O. Iwu, F. Simone, E. Ciliberto, C. Spinella, S. Mirabella, J. Phys. Chem. C 118 (2014) 28189-28195.

[80] H. Jiang, J. Hu, F. Gu, C. Li, J. Alloys Compd. 478 (2009) 550-553.

[81] J.M. Stiegler, R. Tena-Zaera, O. Idigoras, A. Chuvilin, R. Hillenbrand, Nat Commun 3 (2012) 1131.

[82] Z. Chen, L. Gao, Cryst. Growth Des. 8 (2008) 460-464.

[83] K.-W. Chae, Q. Zhang, J.S. Kim, Y.-H. Jeong, G. Cao, Beilstein J. Nanotechnol. 1 (2010) 128-134.

[84] R.A. Laudise, A.A. Ballman, J. Phys. Chem. 64 (1960) 688-691.

[85] Q. Ahsanulhaq, A. Umar, Y.B. Hahn, Nanotechnology 18 (2007) 115603.

[86] X. Yan, Z. Li, C. Zou, S. Li, J. Yang, R. Chen, J. Han, W. Gao, J. Phys. Chem. C 114 (2010) 1436-1443.

[87] D.-F. Zhang, L.-D. Sun, J. Zhang, Z.-G. Yan, C.-H. Yan, Cryst. Growth Des. 8 (2008) 3609-3615.

[88] C. Pacholski, A. Kornowski, H. Weller, Angew. Chem. Int. Ed. 41 (2002) 1188-1191.

[89] P. Samanta, P. Chaudhuri, Front. Optelectron. China 4 (2011) 130-136.

[90] Q. Huang, L. Fang, X. Chen, M. Saleem, J. Alloys Compd. 509 (2011) 9456-9459.

[91] K. Mahmood, B.S. Swain, G.-S. Han, B.-J. Kim, H.S. Jung, ACS Appl. Mater. Interfaces 6 (2014) 1002810043. 
Graphical Abstract
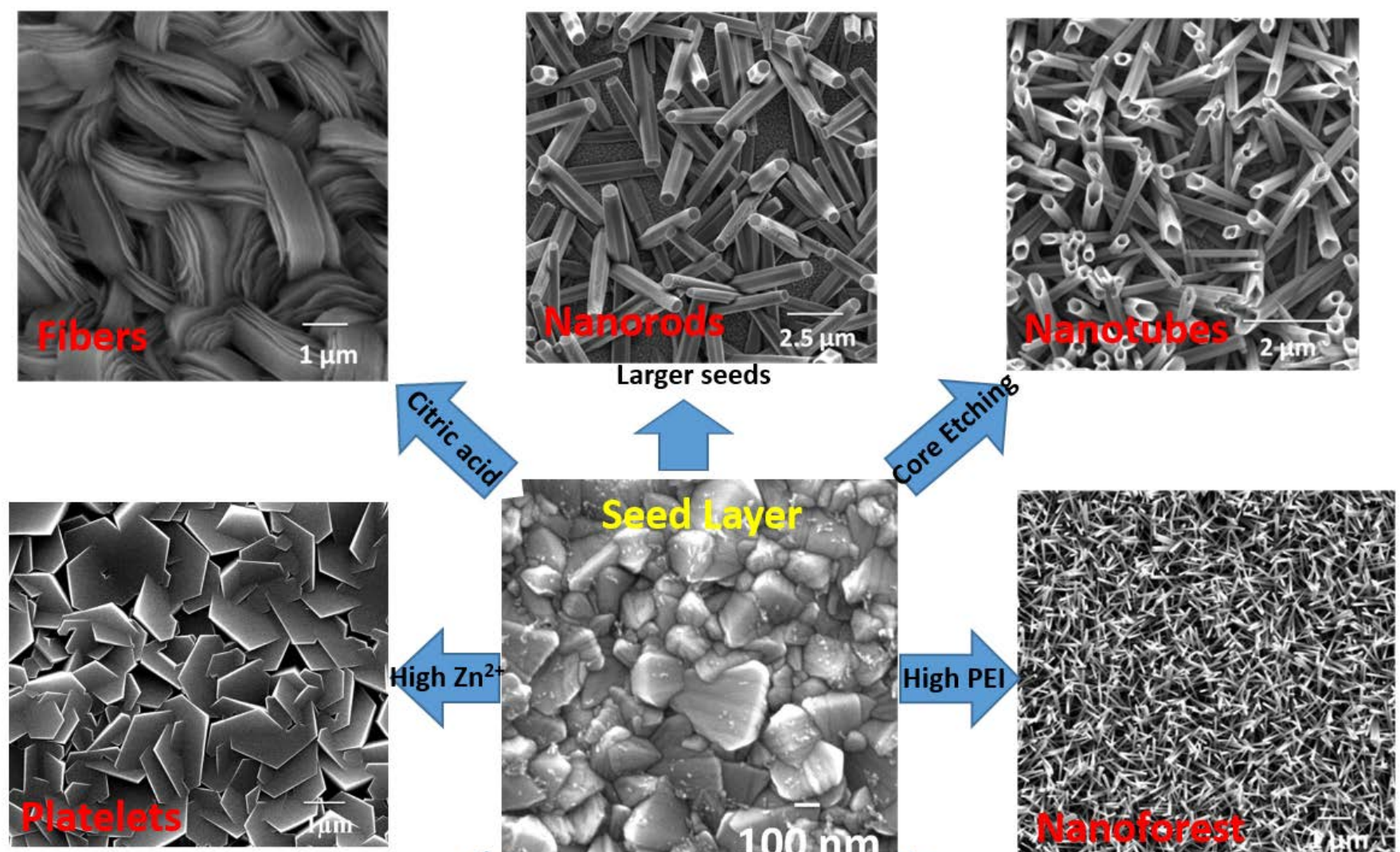
High $\mathrm{Zn}^{2}$

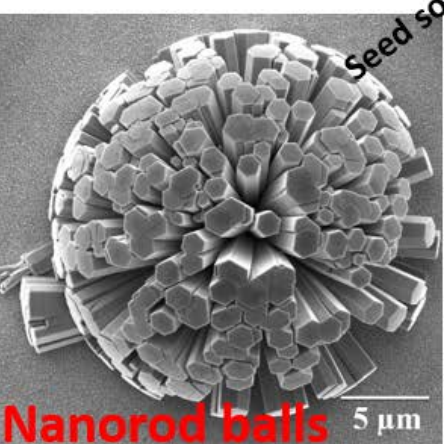

\section{Fresh precursor solution}

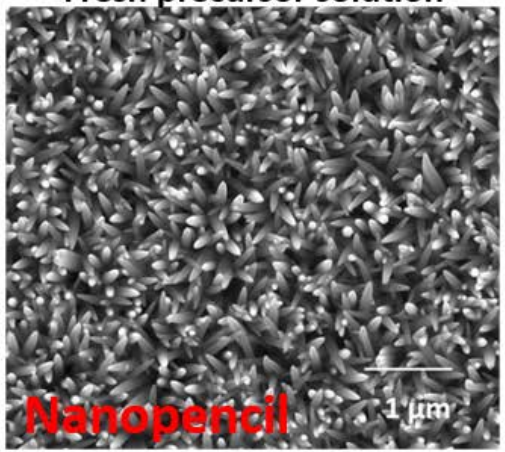

High PEI
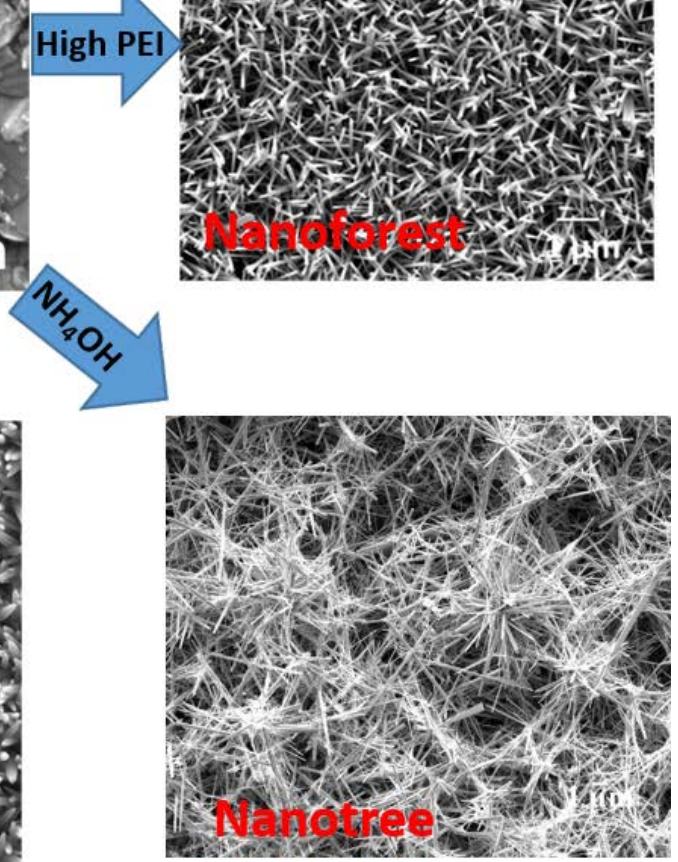